\title{
Euroscepticism and Traditions of Nationalism
}

\author{
Zekeriya Alperen Bedirhan \\ Ugur Ozgoker
}

\begin{abstract}
The European Union and its member states are in the effect of populism and its catalyzer populist parties. Most of populist parties are the right-wing parties and their politic discourses can be called nationalist. In this study, relations between tradition of nationalism within the context of its historic roots and in the current use, and Euroscepticism will be examined. European identity will be discussed as an important integration factor and populist parties of the European zone will be analyzed with internal and external factors.
\end{abstract}

Keywords: Euroscepticism, Nationalism, Populism, Populist Parties, Euroepan Union, Identity Politics

\section{Introduction}

The project of European integration or the European Union has been confronted with opposition ideas called Eurosceptism. According to European Commission president Jean-Claude Juncker, "Rising Euroscepticism and domestic political point-scoring pose an existential threat to the European Union." (Boffey, 2017). However, what are the main reasons for the Eurosceptic movement? From the European Coal and Steel Community (ECSC) to the EU, this sui-generis organization was transformed from economic cooperation to political union and this top to bottom evolution in the organisation has disturbed some political groups and created origins of Eurosceptism. In other words, the supra-national character of the EU is seen as a threat to the sovereignty of nation-states by this Eurosceptic movement. Within the context of this argument, radical right parties as well as left parties use this idea as propaganda against the European Integration in their negative stance. "Radical left and right wing eurosceptism have a common denominator which is nationalism." (Halikiopoulou, Nanou and Vasilopoulou, 2012: 504) However, can this relation between Eurosceptism and nationalism be generalized and applied in the entire European continent by political scientists? To what extent does Euroscepticism reaffirm or 
challenge traditions of nationalism? The aim of this article is to answer these questions with examples of European countries, especially France and Greece.

\section{Tradition of Nationalism and Eurosceptism}

The European nation-state system was framed by nationalism because of the raison d'être of modern state structure since the French Revolution. Mostly, nationalism was a tool of patriotism, national unity and sovereignty in nation state borders. Unfortunately, the concept of nationalism was expanded and abused with discourses by political leaders to execute expansionist policies, conflict and war. On the other hand, "at various times, nationalism has been progressive and reactionary, democratic and authoritarian, liberating and oppressive and left wing and right wing." (Heywood, 2002: 115). According to Heywood (2002: 115), nationalism can be classified into four; liberal nationalism, conservative nationalism, expansionist nationalism and anti-colonial nationalism. Therefore, the definition of nationalism is relative. Moreover, nationalism is not strong in the case of ethnic, cultural and linguistic differences which occur between different ethnic origins. The United States of America and Canada are examples which show that a supra-nation identity can be constructed to promote national unity, and this approach destroys the necessity of main elements for a classic definition of nation like common language, history, tradition and ancestral blood ties. Moreover, current international politic system witnessed migrations, thanks to globalization and this movement disturbed homogeneity of population. Reactions showed that these developments were not welcomed by some radical political parties. As a result, racism, xenophobia, a fear and hatred against foreigners occurred.

In this nation-state system, the EU tried to change its structure from an economic organization to a political unit which aims to establish a federal Europe in the brand of 'The United States of Europe' which was first coined by Winston Churchill. (Packwood, 2016: 2). However, opposition ideas and criticism against the EU project and the EU policies are made by Eurosceptics who think that the EU weakens the nation-state sovereignty. Eurosceptism can be classified into two; hard Eurosceptism and soft Eurosceptism. Hard Eurosceptism is the rejection of the entire EU project which is economic and political integration and it defends the leaving of the EU. Mostly, it is articulated by right parties. (Condruz-Bacescu, 2014: 56). On the other hand, soft Eurosceptism is interested in criticism of one or more policies of the EU, like economic crisis, democracy deficit and immigration problems and it is basically reformist. (Bertoncini, Koenig, 2015: 6) However, this classification is seen as too broad and not specific. An alternative classification of the term is offered by Kopecky and Mudde (2002: 300-301) which are Europhobe/Europhile and EUoptimist/pessimist axes to analyze different types of party positions. This categorization can be expanded with; "Euroenthusiasts" who are close to proEuropeanism; secondly, the "Eurorejects" who are against the European integration; 
"thirdly, the "Eurosceptics" who support the idea of a united Europe but disagree with the general practice of integration; and finally, the "Europragmatists" who are against the idea of the EU but support the practice of European integration." (Vasilopoulou, 2009: 5).

Beyond the theoretical discussions of Eurosceptism, it is believed that Eurosceptism started with the Maastricht Treaty, because as a symbol of political unity, a single currency 'Euro' was formalized and a lot of countries did not accept it. This disagreement on single currency can be examined within the context of eurosceptism and nationalism, especially conservative nationalism as a main defender of Eurosceptism. A project of federal Europe is a threat for conservative right parties, this idea argues that European integration burdens potential destruction of nationstates. For instance, the United Kingdom possesses a special or privileged status in the EU. She did not join Eurozone and Schengen area. "Also, she gained an opt-out from the Charter of Fundamental Rights of the European Union, and refused to sign the fiscal compact." (Mourlon-Druol, 2018). Not only national interests but also traditions, symbols like existence of the Royal Family played important role in the case of the isolation of the UK from the EU.

The leadership of the EU has tried to halt the Eurosceptic movement. However, since 1999, actors of anti-European parties have begun to show resistance against the changing character of the EU. For example, "The Treaty establishing a Constitution for Europe" was rejected by some members of European Parliament (MEPs) under the new founded group called "Independence and Democracy". In 2005, French and Dutch European constitution referendums resulted in a win for the 'NO' campaign, but the Lisbon Treaty solved disagreements and determined the future of the EU which is based on agreements. Dissatisfaction within the Member States has become stronger in the wake of the Eurozone debt crisis and refugee crisis. Provisions of the EU increased the Eurosceptic movement and resulted in Brexit which was against hierarchy and elitism according to Michael O'Neill (O'NEILL, M., 2018). As mentioned above, British exceptionalism was a part of the integration problem in the European identity but the main reason was the EU's decision on the refugee quotas and immigration which increased eurosceptism in the UK.

Main executors of these Eurosceptic activities are radical parties in the EU. They can be classified into two; radical right and radical left parties. Features of radical right parties are nationalism, authoritarianism and populism. (Mudde, 2010) Mostly, right parties focus on immigration, national identity, domestic security and cultural or moral deterioration in the society. Radical left parties improve their party policies on the systematically critical of neo-liberal capitalism and globalization (March, 2012: 1725 ) and European integration is a barrier for this aim. Mostly, as a strategic maneuver to catch up all electorate, importance of nationalism in these radical parties can be seen in the elections rather than paying attention to their ideologies, values 
and beliefs. Therefore, new populist parties which is connected with the radical right and new politics parties and their predecessors the old left constitute unorthodox strategies.

Main arguments of eurosceptic radical right parties defend that the EU is a source of assimilation of identities, loss of sovereignty, external threat for independence and unity. On the other hand, radical left parties defend that the EU is the executor of capitalist or free market economy to exploitation and imperialism, violator of economic and social rights against the equality and internationalism and threat to the territorial integrity. But "these radical parties share elements of nationalist ideology leading to a common eurosceptic stance." (Halikiopoulou, Nanou and Vasilopoulou, 2012: 505) Fundamentally, structural and ideological background of these radical parties are incompatible for this notion but in the EU politics, to convince the society in the elections, this is the most popular and effective discourse.

\section{Effects of Eurosceptism and Nationalism for European Countries}

Euroscepticism is based on some negative discourses. For instance, democracy deficit in the EU decision making process leads to lack of participation of the electors in the EU elections. Public opinion mostly believe that the EU is operating in 'technocratic' mode (Bretherton and Vogler, 1999: 77). The EU cannot be deepened or widened because of its lack of societal relations and this causes legitimacy problem. Consequently, the EU is not able to become a global leader. It cannot establish a powerful political unit between its member states. In addition to this, the EU is based on mutual agreements that still protect national interests. However, in the case of undermining national sovereignty, voting behavior changes. For example, the Treaty establishing a Constitution for Europe that was a significant step to give more power to the EU, French and Dutch voters rejected it in the referendums, most especially the French voters who felt cheated in the 1992 Maastricht Treaty (Franck, 2005: 1073). The EU replaced it with the Treaty of Lisbon, like a soft transition, but it can be seen that for France, referendums hold significant places to show the relations between eurosceptism and nationalism.

Within the context of referendums, results of the Brexit referendum in the UK was an important sign to not only the future of Europe but also France too because worries on domino effect occurred. Across Europe, rise of eurosceptism can be shown in the poll results. "The Pew Research Center found a majority of people were unfavorable towards the EU in Greece (71\%) and France (61\%)." (BBC News, 2018) In the case of France, Frexit which is the name of French withdrawal from the EU was proposed by the Front National leader Marine Le Pen who called herself as Madame Frexit. Moreover, the refugee crisis in France helped Marine Le Pen in the 2017 presidential election. In the election promises, she defended another referendum like Brexit in France. However, in the election, Emmanuel Macron of 'En Marche!' who is a centrist 
and liberal politician had been elected by a decisive margin. He aims to carry out a reform in the EU to overcome a withdrawal trend from the EU.

Nationalism in France is a very decisive factor in the political issues and French Eurosceptism mostly reaffirms nationalism but it is not able to push the voters to Frexit. First reason to the disadvantage of Eurosceptism in France is that French people became rational and gave a chance to Macron about the EU reforms and solving immigration problems in the presidential race. Another reason is that, after the Islamic terrorist attacks in France, voting behavior was expected to shift radical policies like after 9/11 attacks in the US. However, interesting point is that the 2017 French presidential election was between progressive populist Macron and nativist populist Le Pen. French voters tried to elect one of the populist leaders who follow different ideologies. Therefore, rather than radical policies of Le Pen, French voters were interested in progressive reforms of Macron in the same populist scale.

Like France, refugee crisis in the EU triggered Eurosceptic movements with populist far right ideas in European countries. There are a number of Europeans who still continue with their task to welcome and also support the influx of refugees. However, in certain places, the influx of immigrants to the country would fall as a play in the populist parties' hands and even to the right-wing movements. Austria has already made a declaration for a quota for the immigrant asylum seekers. Alternatively, Greece is struggling to cope with the refugee backlog that are restricted from crossing into Macedonia. Between Sweden and Denmark, the temporary controls are well in place, and these temporary controls are also at different other borders of the generally Schengen area which is passport-free. (Traynor, 2018) In Spain and Italy in 2015, population between 60 to $80 \%$ had reported to the pollsters about their being unhappy regarding their governments' immigration policies. The anti-migration AfD party in a few areas in Germany surpassed the mainstream Social Democrats. Migration would have been a decisive factor in the UK, regarding the in-out referendum, whereas the incumbent governments in other EU countries would be adopting a tougher stance related to migration for re-capturing voters which had been drifting towards the populist challengers. This kind of domestic pressures related to politics might, in turn, make it difficult for the governments at the EU level to have workable compromises without which there is going to be more fragmentation in the EU. Kentmen-Cin and Erisen (2016: 3) stated that there is yet a scope in Europe to turn the migration crisis into the shape of political and economic opportunity, but the window is witnessed to close very fast.

Refugee crisis in the Europe is one of the main reason which triggers tradition of nationalism and causes Eurosceptism. However, in the case of Greece, a different approach and version of Eurosceptism can be seen because of the Eurozone economic crisis. The solution for the voters who suffered from the Greek government-debt crisis in the 2015 general election was the Syriza and its leader Alexis Tsipras whose 
ideology is based on left-wing populism and soft eurosceptism. Generally left-wing parties defend cross-border solidarity, however, since the 1940s there has been a rise in left-wing nationalism which uses nationalism for social cohesion against the difficulties like exploitation, anti-imperialism and foreign interventions. Syriza is not an exception to this left-wing nationalism but "its patriotic rhetoric has ditched its Eurosceptic platform." (Papadogiannis, 2018) It can be seen that Syriza moderated its ideology and softened its approach towards Greek withdrawal from the EU or Grexit and this helped the popularity of Syriza. The Communist Party of Greece (KKE) and Popular Unity which split from Syriza supports leaving the euro but these parties cannot satisfy voters' expectation and received less votes in the elections. Because, for the voters, pros of Syriza was different from other parties. For them, Syriza brings back hope and defends dignity of the Greek people but in fact as a populist party, Syriza has linked with 'underdog culture' which shows a society that lives in an economically vulnerable country, fears international competition and feeds populist leaders. (Stavrakakis and Katsambekis, 2014: 120)

\section{Conclusion}

Is the tradition of nationalism an existential problem for the European integration? Eurosceptism claims that the EU is against the nation-state system. As a method to continue nation-state's power or status quo in the EU, Eurosceptism is an opposition idea and mostly pessimistic criticisms about the current structure and policies of the EU. In this perspective, it can be said that the tradition of nationalism is reaffirmed by Eurosceptism.

In this article, some of the challenges between Eurosceptism and traditions of nationalism are tried to be found. It can be seen that nationalism is based on identity which is basically, who you are. At this point, Eurosceptics use identity for its purposes. Eurosceptism believes that the EU project which wants to establish 'the United States of Europe' is against the nation-state system and it weakens the sovereignty of the nation-states. Especially, not only nation-state level but also supranational level, Eurosceptic right parties or ideologies use nationalism to enforce its discourses more than left parties. In the common aim which is to weaken the EU project, Eurosceptic left parties which are ideologically against the nationalism to destroy class system and to unite a society based on left ideology, compromise with Eurosceptic right parties. Like differences between hard and soft Eurosceptism, Eurosceptic left and right parties brought different approaches on nationalism while criticizing the EU.

Therefore, there is a link between nationalism and eurosceptism but the fact that to reach their political ambitions, a lot of populist parties in Europe abuse nationalism and accuse the EU for the crisis with Eurosceptic ideas. Therefore, after a while, the EU became a scapegoat for failures, debts and crisis in the nation-states. In fact, 
Eurosceptism is a political tool for the populist parties in Europe to maximize their sympathizers rather that change their minds.

\section{Bibliography}

[1] BBC News. (2018). Euroscepticism on rise, poll suggests. [online] Available at: http://www.bbc.co.uk/news/uk-politics-eu-referendum-36471989 [Accessed 5 Mar. 2018].

[2] Bertoncini, Y., \& Koenig, N. (2015). Euroscepticism Or Europhobia: Voice Vs. Exit?. Notre Europe.

[3] Boffey, D. (2017). Rising Euroscepticism 'poses existential threat to EU'. [online] the Guardian. Available at:

https://www.theguardian.com/politics/2017/mar/03/brexit-has-put-otherleaders-off-wanting-to-leave-says-ec-vice-president [Accessed 24 Dec. 2017].

[4] Bretherton, C., \& Vogler, J. (1999). The European Union as a global actor. Psychology Press.

[5] Condruz-Bacescu, M. (2014). Euroscepticism across Europe: Drivers and challenges. European Journal of Interdisciplinary Studies, 6(2), 52.

[6] Franck, R. (2005). Why did a majority of French voters reject the European Constitution?. European Journal of Political Economy, 21(4), 1071-1076.

[7] Halikiopoulou, D., Nanou, K., \& Vasilopoulou, S. (2012). The paradox of nationalism: The common denominator of radical right and radical left euroscepticism. European journal of political research, 51(4), 504-539.

[8] Heywood, A. (2002). Politics (palgrave MacMillan). New York.

[9] Kentmen-Cin, C. and Erisen, C., 2017. Anti-immigration attitudes and the opposition to European integration: A critical assessment. European Union Politics, 18(1), pp.3-25.

[10] Kopecky, P., \& Mudde, C. (2002). 'The two sides of Euroscepticism', European Union Politics, 3(3), pp. 297-326.

[11] March, L. (2012). Radical left parties in Europe. Routledge.

[12] Mourlon-Druol, E. (2018). Brexit debate ignores UK's privileged position in Europe | Bruegel. [online] Bruegel.org. Available at: http://bruegel.org/2016/05/brexit-debate-ignores-uks-privileged-positionin-europe/ [Accessed 5 Jan. 2018].

[13] Mudde, C. (2010). The populist radical right: A pathological normalcy. West European Politics, 33(6), 1167-1186.

[14] O'NEILL, M., (2018), Challenges to the western liberal order: the end of 'the west'? Research Seminar, Nottingham Trent University, Nottingham, 24 January 2018.

[15] Packwood, A. (2016). Churchill y los Estados Unidos de Europa, 19041948. Comillas Journal of International Relations, (7), 1-9. 
[16] Papadogiannis, N. (2018). Power to Our People. [online] Foreign Affairs. Available at: https://www.foreignaffairs.com/articles/greece/2015-0921/power-our-people [Accessed 11 Mar. 2018].

[17] Traynor, I. (2018). Is the Schengen dream of Europe without borders becoming a thing of the past?. [online] the Guardian. Available at: https://www.theguardian.com/world/2016/jan/05/is-the-schengen-dreamof-europe-without-borders-becoming-a-thing-of-the-past [Accessed 4 Mar. 2018].

[18] Vasilopoulou, S. (2009). Varieties of Euroscepticism: the case of the European extreme right. Journal of Contemporary European Research, 5(1), 3-23.

[19] Yannis Stavrakakis \& Giorgos Katsambekis (2014) Left-wing populism in the European periphery: the case of SYRIZA, Journal of Political Ideologies, 19:2, 119-142, DOI: $10.1080 / 13569317.2014 .909266$ 